\title{
APPLICATION OF INFORMATION TECHNOLOGY AND E-BUSINESS IN OPTIMIZING THE COMPETITIVE ADVANTAGES OF SMALL AND MEDIUM-SIZED ENTERPRISES
}

\author{
Aleksandar Damnjanović and Zoran Jovanović \\ High School of Academic Studies "Dositej", Belgrade, Serbia \\ Predrag Vukadinović \\ Singidunum University, Belgrade, Serbia
}

\begin{abstract}
In order to review and study the issues of competitiveness and opti-
Imization of business operations with the use of IT and e-business, the paper will study, analyze and elaborate on the several key criteria formulated in research questions. Exploration of these questions through desktop and empirical research examines in detail the role and impact of new technologies, especially information technology in optimizing the competitive advantages of small and medium-sized enterprises. Research eventually assesses the degree of optimization of technological inputs and outputs in the development of competitive capacity of SMEs and offers appropriate conclusions.
\end{abstract}

Key words: investing, innovations, new technologies, competitiveness, global market

\section{Introduction}

Information technologies and electronic business have one of the more important roles in creation of competitive advantages for SMEs, on local and global market too. All global market players certainly have one common thing - use of ICT. It is impossible to imagine a global world company not using ICT. (Veljović at al., 2009).

Adequate adjustment of IT possibilities to the SMEs strategic goals is a key for success in modern enterprises. SMEs exist and operate in the fields of retail, wholesale trade, service sectors and in production of highly specialized demand (Vemić, 2008). Use of IT is basic factor in the enhancement of business performances of an enterprise. Change of production technology caused radical changes within organization of enterprises at one time; in the same way, radical changes are happening today under the influence of IT - which is becoming foundation of modern business (Bešić at al., 2009). Business success is realized through its elements (factors) (Bešić at al., 2010).

At the centre of the EU development strategy is innovativeness. Innovative organizations are characterized by their skill to direct creativity toward beneficial results. (Ranđić and Lekić, 
2009). Innovative lag is the biggest one in the field of intellectual property. Organizations - in the spirit of competitive fight - are oriented to finding personal advantages (Papić, 2011).

Increase of competitiveness of SMEs is becoming the most important direction within further economic development. Contemporary business environment does not question introduction of enterprises' changes, but it is interested in the way and speed the changes are conducted. (Milošević, 2014). Constant adaptation and presentation at the market of new or changed products and services are foundation for the enterprises' increase in modern economy (Milosavljević, 2006).

Questions of application of IT and E-business in optimization of SMEs competitive advantage are research subjects in this work. Internet infrastructure is now used for mutual coordination and synchronization of activities in business process. (Živadinović, 2010). E- commerce represents business communication and transfer of goods and services (buying and selling) through networks and computers, as well as transfer of capital using digital technologies. (Jokić and Mikić, 2008)

\section{Optimization of Competitiveness through IT and Electronic Business}

At the Summit EU - Western Balkans held in mid-2003 in Thessaloniki, the various Western Balkans countries (Albania, Bosnia and Herzegovina, the former Yugoslav Republic of Macedonia, Serbia and Montenegro) adopted the European Charter for Small Enterprises. The Charter was adopted in the framework of the Lisbon agenda to improve cooperation between the member states of the European Union and the countries of the Western Balkans. It reflects the commitment of countries to SMEs as a major source of new jobs, innovation, economic dynamics and social inclusion. Since its adoption the Charter has become the main platform for pursuing policies optimal for the development of small enterprises and entrepreneurship in the region.

In addition to the European Charter, the European Commission in 2010 also adopted the Strategy for smart, sustainable and inclusive economic growth - or briefly Europe 2020. This strategy builds on the Lisbon Strategy, which defines the main principles for formulating an effective policy for the development of SMEs. All objectives of the strategy are aimed at increasing employment, strengthening research and innovation, education, reduction of greenhouse gas emissions and boosting energy efficiency and fighting poverty.

The strategy defines these three main operational objectives:

1. smart growth - implying economy optimization based on knowledge and innovation;

2. sustainable growth - implying stimulation of the optimized economic competitiveness, optimal and efficient use of resources, while taking into consideration the conditions of globalization;

3. inclusive growth - fostering growth of employment and education, social protection systems and combating poverty.

Since 2009, monitoring of the implementation of this strategy and the progress of SMEs reform policies in the Western Balkans has been effectively carried out.

The economic environment in Western Balkan countries is therefore based on the progress of the market economy and private sector development. 
Technological process makes the basis for economic modernization aiming to enhance the efficacy, rationality and business economy, compatibility of communication system among all participants globally. There is a conception about global processes as being encouraged by technological achievements, which means that globalization is the fundamental tendency of technological progress. Therefore, globalization is originally defined through reference to the development of technology, communication, information progress - which makes the world more or less inter-dependent in many ways (Šarac at al., 2015).

However, besides some minor improvements of economic trends in the region, the trend of negative business development continues in most countries, which requires further efforts towards optimizing key factors of production.

Organizations, ready to accept flexibility and change, are necessary nowadays (Albijanić, 2013).

Innovation implies improvement of the existing product, creation of a new product, improvement of the production process or admittance into new marketplace (Njeguš, 2009).

According to leading economists and relevant researches cited in the paper, the three reform areas that can assist the Western Balkan countries and allow them to quickly overcome the crisis, are as follows: continued fiscal consolidation, improvement of business climate and optimization of knowledge and skills necessary for economic development. According to the World Bank these three reform areas alone could have contributed to an average rate of economic growth in all five countries of the Western Balkans of around 1.7 percent in 2013. This paper explores the third pillar as knowledge management optimization through IT and e-business utilization.

Within this framework optimization of competitiveness through IT and electronic business is considered among the most important issues in many countries and companies.

General companies' orientation towards world market resulted in tremendous mobility of goods and services, and in enrichment of the market offer - which became part of global market ambience (Ivković at al., 2012).

Information technologies enable new methods of information interchange - which represents the most valuable business resource of today. New technologies encourage development of new organizational forms and structures, i.e. innovative business methods (Obradović at al., 2011).

The struggle for competitiveness is not just between companies on a national and regional level but also between countries at international level.

Companies' strategy may vary from country to country, but, for the promotion of success on the external market, internal competitiveness is important - since 'healthy competitiveness' is fruitful ground for innovation (Jednak, 2008).

Measuring the competitiveness of the national economy is of particular importance, given that it contributes to the advancement of business and overall economic growth.

Basis for SMEs management represents management based on innovations, since only such management that stimulates innovations enables survival and growth (Avlijaš, 2008).

If competitiveness in the global market is poor, then the national economy suffers, leading to protectionism, non-transparent government subsidies and barriers to enterprise development.

The biggest change on the labor market was introduced by information technologies, which directly influenced business methods as well as costs reduction in different fields (Jeremić, 2016). 
Optimization through IT and e-business is an effort to counter such trends.

Web technology, i.e. application of the newest technological achievements is a tool used by companies in order to attract new customers, but also to strengthen communication with the existing ones (Ratković at al., 2011).

Since 2005 the World Economic Forum has based its analysis of the competitiveness on the Global Competitiveness Index.

Organizations that want to be globally competitive must be capable of fast transformation (Mašić, 2010).

This is a very comprehensive index that includes micro and macroeconomic foundations of national competitiveness.

Enterprises not able to use technology optimally will always lag behind, and perhaps they will not survive aggressive competitiveness (Bugarić, 2010).

In order to rank the national economy, this methodology takes into account the key factors and systematizes them in institutions, infrastructure, macroeconomic environment, health and primary education, higher education and vocational training, goods market efficiency, labor market efficiency, financial market development, technological readiness, market size, business sophistication and innovation, which are all the key optimizing factors in IT and e-business.

Introduction of new information technologies implies: enhancement of business procedures and of work efficacy, simplification and speeding-up of practical work, costs reduction, improvement of employees' productivity and saving of clients' time (Vukadinović and Jović, 2012).

Comparing the Balkan countries with developed European countries in terms of optimizing competitiveness, it is evident that they are lagging far behind in reducing the existing difference compared to other EU countries. This could have negative implications in terms of approaching EU membership and participation in European integration trends. In order to reduce this lag, it is necessary for economic national policies of the Balkan countries to reduce high operating costs, high tax levies, huge public debt, high unemployment, resolve difficulties in the liquidation of enterprises and create a positive business climate that would optimize competitiveness and innovation in the global market.

Innovations, among other things, are conditioned by the environment in which entrepreneurs operate. Environment generates creation and innovation. Environment in which innovations are used affects also their results (Ožegović and Sajfert, 2009).

The Internet as the largest and most popular global computer network, also known as an information highway intended for data exchange, is underutilized in the Balkan countries in terms of competitive optimization.

Changes within external environment initiated qualitative changes in business orientation of enterprises (Damnjanović and Milisavljević, 2009).

Conclusions of this work advocate establishing computer networks between all the relevant scientific and business institutions, the use of e-business and computers as well as technology of packet transmission for the mutual exchange of information.

In modern, global, business environment, with focus on the Internet, crucial moment represents perfect communication between the manager and other participants (Milosavljević at al., 2013).

ICT is the key advanced technology and it is an initiator of innovations and productivity in the overall EU economy (Jevtić at al., 2011). 
This technology allows the sharing of information in smaller packets and then sending them to specific computers. The Balkan countries could advance in the optimization of business competitiveness with the application of this technology. This will allow connections and exchange of data between different business computer networks.

'Ambience information' (business and general ambience) comprise: a scale of different data related to demography (population), social and material relations (salaries, pensions and other allowances), technical and social progress, fashion, politics and legislation and other processes and relations important for the companies' success (Jokić, 2010).

Closed computer network of dedicated professionals grows into open-ended networks in order to optimize competitiveness of enterprises. On a commercial basis internet facilities thus become a factor in optimizing competitiveness of enterprises. The Internet is thus becoming a network of a large number of networked computers around the world that are interconnected by optic cables, telephone lines, satellite links and other forms of communication connection, which operate on the basis of specific optimized business protocols. This network enables seamless two-way communication between all participants in the optimized business information traffic.

In terms of this paper Internet is a computer network infrastructure that is built by a specific standard used by all users, connected to each other by using TCP / IP, as well as individual business networks that form a single logical network in which all share a common addressing scheme.

In today's information society the Internet is a global communications medium and as such it is a factor optimization in terms of our research.

Digital economy led from industrial economy to the economy characterized by: information, immaterial property, non-transparent values, services, new organizational methods and institutional reforms (Njeguš, 2010).

Networks within and outside the company have their own services for business optimization. Business services are a set of functions packaged as a single entity and set up somewhere on the Internet to ad hoc serve other optimized programs and networks. The competitiveness of services and optimization in this regard can be grouped into: public services, basic business services, commercial search services, security services and system business services.

Web is one of the most important Internet services for business optimization. It allows access to multimedia and distributed databases in developing competitiveness and optimization of the company management functions. Using text, graphics, multimedia, and related files, it forms a vast network of easily accessible data.

In order to review and study the issues of competitiveness and optimization of business operations with the use of IT and e-business, the paper will study, analyze and elaborate on the following key criteria formulated in research questions: Optimizing electronic forms of communication and web site, the degree of management effectiveness, optimizing customer management and related web site material, the development of management systems and procedures for electronic responses and appeals, channels of internal communication, cooperation mechanisms between organizational units of the company, optimizing knowledge management, modernization of enterprises and employees, the level of use of modern information, development of employees and partners, financing the development of employees in the information sector, the budget for information technology, financial investments in information technology, innovative knowledge management in budget planning, the benefits of electronic payment cards, communication of employees and 
company management, innovation in the field of information technology, progress arising from the use of new technologies, the level of commitment of management to introduce new information technologies and employee motivation to manage new technologies.

Exploration of these questions through desktop and empirical research examines in detail the role and impact of new technologies, especially information technology in optimizing the competitive advantages of small and medium-sized enterprises. Research eventually assesses the degree of optimization of technological inputs and outputs in the development of competitive capacity of SMEs and offers appropriate conclusions.

\section{Subject, Starting Points and Goals of Research}

Subject of research in this work is application of IT and E-business in optimization of competitive advantage of SMEs. Fast changes in places where SMEs conduct their activities lead to the constant finding of answers in relation to challenges that they are exposed to. Answer to this question is found in the advancement of strategic competitive features, through application of IT and E-business.

New business forms are made due to the quick development of ICT, which become basis of modern business. In order to survive at the market, SMEs must conform to the new challenges and rules imposed by modern environment. Because of the competition challenges, advantages of modern IT must be recognized by top management.

On the basis of previous statements goal of the work is defined as: Application of IT and E-business in optimization of competitive advantage of SMEs as advancement of overall performances of organization.

Target group treated in this work are SMEs which present a huge part of Serbian economy and have the biggest impact on development of economy.

Research starts with hypothesis that with application of IT and E-business optimization of SMEs business can significantly improve and create competitive advantage.

\section{Basic Hypothesis of the Research}

Through theoretical, empirical and desk research, hypothesis set in this work is testing impact of ICT and E-business on competitive advantage of SMEs.

Hypothesis: Optimization of SMEs business through IT and E-business had positive impact on competitiveness in the research period.

\section{Methodological-theoretical Framework of the Research}

Statistical analysis of basic and control variables is used in this work for testing the hypothesis and results of empirical research.

With regard to the theoretical worthiness of statistic methods used in the research methods are divided into two basic groups. 
Basic method of descriptive statistical analysis of the observed data represents the first group. In this way we will define dominating characteristics of the observed group, calculate basic parameters, mean values and standard deviation for the hypothesis within the sample.

In the second phase of statistical analysis of the observed data we conduct statistical testing of dependable variables using Pearson's independence test.

\section{Research Methodology}

With testing the hypothesis through empirical and desk research, we test positive impact of business optimization on competitiveness.

Eventual positive impact on competitiveness is explored, where suitable survey questions are as follows:

1. Is active policy of customers informing optimized by electronic communication forms, especially about plans, activities, decisions and services of the company? ers?

2. Does company use user-oriented web presentations to optimize control of custom-

3. Are modern information technologies sufficiently used within information management?

4. Is part of the annual budget intended for information technologies?

5. Are modern information technologies sufficiently used for the purpose of collection of information?

Above stated hypothesis is tested with empirical research and statistical analysis. Sample of 137 SMEs is formed, of which 103 are small and 34 medium enterprises.

Survey questions are formulated in such a way that they can confirm accuracy of the hypothesis. Answers of the surveyed respondents are coded with 0 (negative answer) and with 1 (positive answer). Answers derived in this way are perceived as dichotomous chance variables, with two values: 0 and/or 1 .

\section{Research Results}

We present now suitable conclusion of the defined hypothesis, which understands positive impact on competitiveness with optimization of business. Formally, we introduce adequate dichotomous variables, which show (negative or positive) answers of the respondents. On the basis of the respondents' answers, variable (survey question) takes one out of two values:

- Yes (value - 1)

- No (value - 0)

Data gained in this way are quantified with especially introduced dichotomous (0/1) variables, or so-called indicators of the observed feature within the sample. 
Table 1 - Interview Questions

\begin{tabular}{|l|r|r|r|r|r|r|}
\cline { 2 - 7 } \multicolumn{1}{l|}{} & \multicolumn{1}{c|}{$\mathbf{1}$} & \multicolumn{1}{c|}{$\mathbf{2}$} & \multicolumn{1}{c|}{$\mathbf{3}$} & \multicolumn{1}{c|}{$\mathbf{5}$} & \multicolumn{1}{c|}{ Mean } \\
\hline $\begin{array}{l}\text { 1. Is active policy of customers informing } \\
\text { optimized by electronic communication forms, } \\
\text { especially about plans, activities, decisions and } \\
\text { services of the company? }\end{array}$ & $0 \%$ & $9 \%$ & $36 \%$ & $9 \%$ & $46 \%$ & 3.91 \\
\hline $\begin{array}{l}\text { 2. Does company use user-oriented web } \\
\text { presentations to optimize control of customers? }\end{array}$ & $32 \%$ & $9 \%$ & $14 \%$ & $14 \%$ & $31 \%$ & 3.04 \\
\hline $\begin{array}{l}\text { 3. Are modern information technologies sufficiently } \\
\text { used within information management? }\end{array}$ & $9 \%$ & $4,50 \%$ & $14 \%$ & $23 \%$ & $50 \%$ & 4.00 \\
\hline $\begin{array}{l}\text { 4. Is part of the annual budget intended for } \\
\text { information technologies? }\end{array}$ & $4.50 \%$ & $9 \%$ & $18 \%$ & $31.50 \%$ & $37 \%$ & 3.95 \\
\hline $\begin{array}{l}\text { 5. Are modern information technologies sufficiently } \\
\text { used for the purpose of collection of information? }\end{array}$ & $0 \%$ & $9 \%$ & $36 \%$ & $23 \%$ & $32 \%$ & 3.77 \\
\hline
\end{tabular}

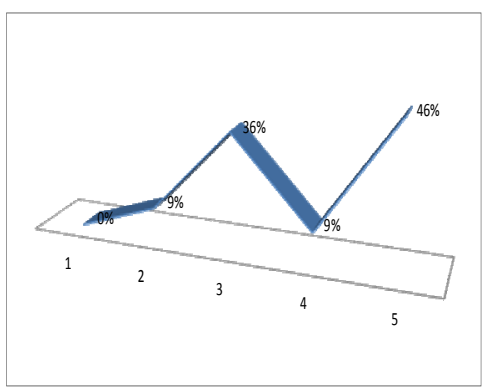

Figure 1 - Mean $3.91 \%$

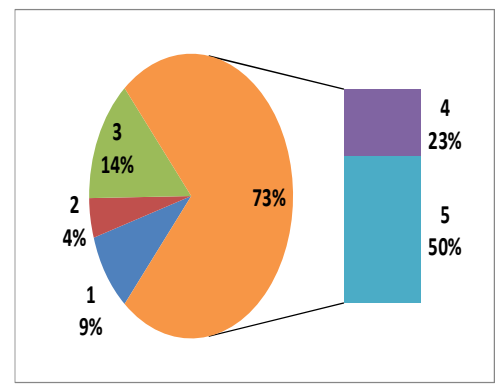

Figure 3 - Mean $4.00 \%$

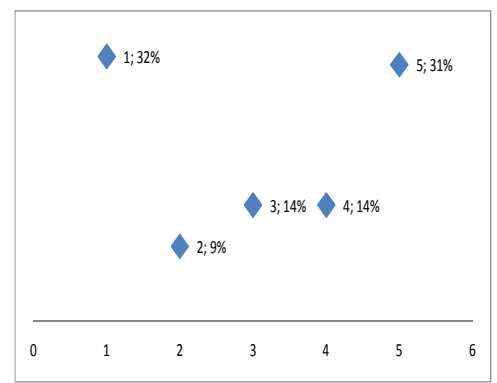

Figure 2 - Mean 3.04\%

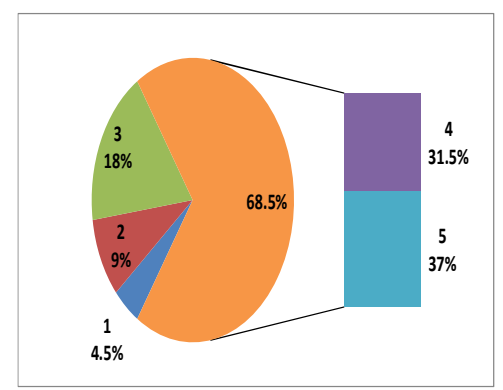

Figure 4 - Mean 3.95\%

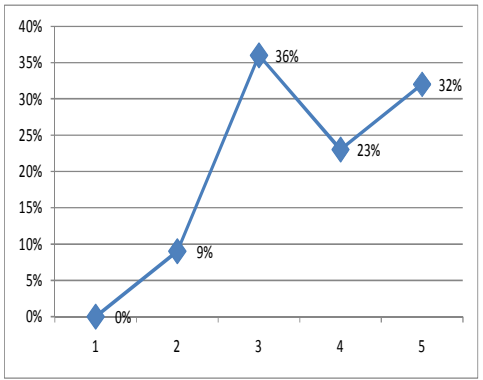

Figure 5 - Mean $3.77 \%$ 
We examine, then, validity of hypothesis which supposes that investments in SMEs innovations and new information technologies in previously explored period had positive impact on relationship with the consumers. Part of the interview survey concerning this hypothesis has five questions, i.e. adequate dichotomous variables, whose observed values, along with the rest of descriptive-statistic indexes are displayed in Table 1.

Variable $X_{3}$ has the biggest observed value; it presents positive attitudes of the SME respondents about keeping proactive and regular relations with the customers. Naturally, majority of respondents, $83.58 \%$ of them, answered this question confirmatively. Similarly, variable $\mathrm{X}_{4}$ shows nearly $80 \%$ of positive answers about IT budget planning. As for variable $X_{1}$, more than three quarters of the surveyed SME sample confirmatively answered the question about active policy for customers informing. It is important also to highlight the value of variable $X_{5}$, on the basis of which we conclude that more than $70 \%$ of the respondents sufficiently use modern information technologies for the purpose of collection of information. Variable $\mathrm{X}_{2}$ shows that almost two thirds of SME respondents affirm use of oriented web presentations.

Table 1a - Number of Observations, Mean and Standard Deviation of Key Variables

\begin{tabular}{|c|c|c|c|c|}
\hline Variables & Description (survey questions) & $\begin{array}{l}\text { SME } \\
\text { Number }\end{array}$ & $\begin{array}{l}\text { Proportion } \\
\text { (p) }\end{array}$ & $\begin{array}{l}\text { Standard } \\
\text { deviation }\end{array}$ \\
\hline$X_{1}$ & $\begin{array}{l}\text { Is active policy of customers informing } \\
\text { optimized by electronic communication } \\
\text { forms, especially about plans, } \\
\text { activities, decisions and services of the } \\
\text { company? }\end{array}$ & 108 & 0.8060 & 0.3955 \\
\hline$x_{2}$ & $\begin{array}{l}\text { Does company use user-oriented web } \\
\text { presentations to optimize control of } \\
\text { customers? }\end{array}$ & 38 & 0.2836 & 0.4507 \\
\hline$x_{3}$ & $\begin{array}{l}\text { Are modern information technologies } \\
\text { sufficiently used within information } \\
\text { management? }\end{array}$ & 83 & 0.6058 & 0.4905 \\
\hline$X_{4}$ & $\begin{array}{l}\text { Is part of the annual budget intended } \\
\text { for information technologies? }\end{array}$ & 97 & 0.7080 & 0.4547 \\
\hline$X_{5}$ & $\begin{array}{l}\text { Are modern information technologies } \\
\text { sufficiently used for the purpose of } \\
\text { collection of information? }\end{array}$ & 53 & 0.3869 & 0.4870 \\
\hline
\end{tabular}

(Source: The projection of the authors)

Contrary to previous variables, variable $X_{2}$ decidedly has the smallest observed value, i.e. surprisingly small number of SME respondents, only $28.36 \%$ of them, said that they possess user-oriented web-presentations suitable for each customer individually. The diagram of the proportions of SMEs positive responses is given in Figure 6. 


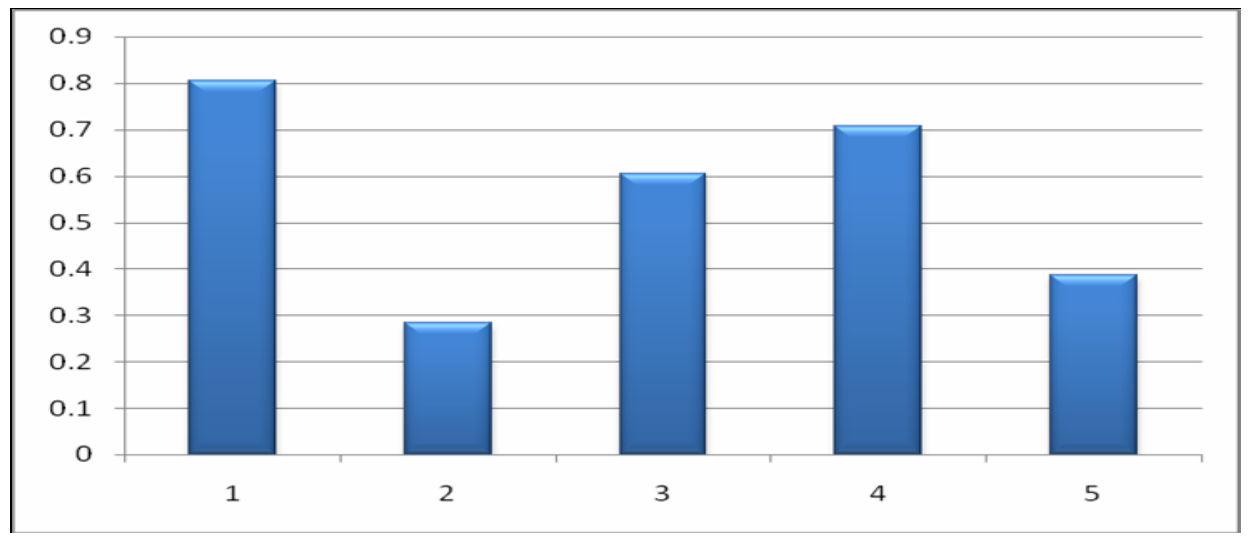

Figure 6 - The diagram of the arrangement of proportions of positive responses of the surveyed SMES (Source: The projection of the authors)

The results of $X^{2}$ testing of the above described variables, observed as the hypothesis modalities, in relation to the size of SMEs, are given in Table 2 . The realized value $X^{2}=12.67$ is slightly smaller than in the majority of the previously obtained values. This is, however, a consequence of the relatively small number of the degrees of freedom $(n=4)$, because $X^{2}$ statistically exceeds the critical values of $X^{2}$ test - at both levels of significance: $p<0.01$ and $p<0.05$. Therefore, with less than $1 \%$ of risk, we claim that there is a statistically significant relationship of the characteristics expressed in dichotomous variables $\left(X_{1}, X_{2}, \ldots, X_{5}\right)$ to the size of SMEs.

Table 2 - The Realized Frequency Values by Size of SMEs and X2 Statistics of the Independence Test

\begin{tabular}{|c|c|c|c|c|c|}
\hline \multirow{2}{*}{ Variables } & \multicolumn{2}{|c|}{ Small enterprises } & \multicolumn{3}{|c|}{ Medium-sized enterprises } \\
\hline & $f_{i}$ & $f_{i}^{\prime}$ & $f_{i}$ & $f_{i}^{\prime}$ & $\Sigma$ \\
\hline$X_{1}$ & 75 & 67.33 & 33 & 40.67 & 108 \\
\hline$X_{2}$ & 21 & 24.68 & 17 & 13.32 & 38 \\
\hline$X_{3}$ & 58 & 57.05 & 25 & 25.95 & 83 \\
\hline$X_{4}$ & 68 & 63.72 & 29 & 33.28 & 97 \\
\hline$X_{5}$ & 25 & 35.09 & 28 & 17.91 & 53 \\
\hline$\Sigma$ & 247 & 247 & 132 & 132 & $X^{2}=12.67^{* *}$ \\
\hline
\end{tabular}

(Source: The projection of the authors)

In other words, a positive impact on relations with customers, realized by investments and innovations in new information technologies, is directly dependent on the size of SMEs. Clearly, we see "dominance" of the medium-sized enterprises - they have expressed more positive attitudes in relation to the majority of survey questions of the hypothesis. This disproportion of affirmative responses is especially high among the $X_{1}$, $X_{3}$ and $X_{4}$ variables that we have previously analyzed. An insight into the formulation of survey questions that correspond to these three variables, clearly shows that responsible 
management system, communication with customers and making of user-friendly websites can be related only to the medium-sized enterprises.

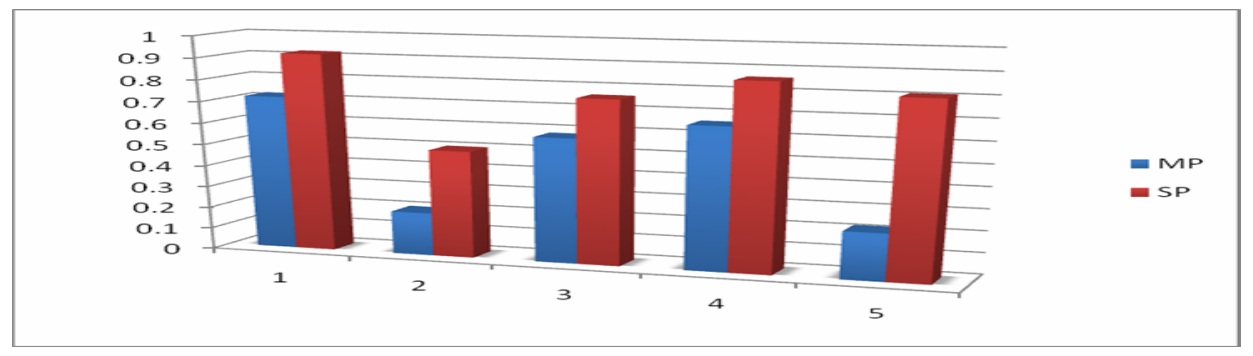

Figure 7 - The comparative diagram of the arrangement of proportions of positive SME responses (Source: The projection of the authors)

\section{Conclusion}

We live in the era of growing globalization of the world market, faster development of modern technologies and their application in business organizations. Our research shows that IT and E-business are very progressively used and applied, and that they represent basis for SMEs competitiveness.

In this work we made statistical analysis of the hypothesis, beginning with descriptive-statistical method and finishing with Pearson's independence test. Conducted statistical analysis was based on the application of important theoretical facts and modern approaches in theoretical-statistical analysis of similar problems. From all above stated, we may conclude that our results and conclusions are absolutely authoritative.

It is important to underline that majority of the respondents confirmatively answered the interview questions, which encourages the fact that SMEs have positive attitude towards IT and E-business.

\section{References}

[1] Albijanić M. (2013). Strategijski menadžment. Beograd: Univerzitet Singidunum.

[2] Avlijaš R. (2008). Preduzetništvo i menadžment malih i srednjih preduzeća. Beograd: Univerzitet Singidunum.

[3] Bagarić I. (2010). Menadžment informacionih tehnologija. Beograd: Univerzitet Singidunum.

[4] Bešić, C., Nikolić, M. i Damnjanović, A. (2010). Strategijski menadžment. Čačak: Fakultet tehničkih nauka.

[5] Bešić, C., Sajfert, Z. i Damnjanović, A. (2009). Menadžment promena. Čačak: Fakultet tehničkih nauka.

[6] Damnjanović, A. i Milisavljević, V. Ciljni marketing. 12. Međunarodna konferencija Upravljanje kvalitetom i pouzdanošću ICDQM-2009, 29-30. jun 2009. (str. 549-556). Čačak: Istraživački centar za upravljanje kvalitetom i pouzdanošću - DQM.

[7] Ivković D., Knežević V., Karavidić S., i Korenak B. (2012). Privredni sistemi. Beograd: Visoka škola za poslovnu ekonomiju i preduzetništvo. 
[8] Jednak J. (2008). Osnovi ekonomije. Beograd: Visoka turistička škola strukovnih studija.

[9] Jeremić Lj. (2016). Savremeno tržište rada. Beograd: Univerzitet Singidunum.

[10] Jevtić, B., Damnjanović, A., Matić, R., i Grozdanić, R. (2011). Izazovi industrijske politike u IKT sektoru. Ekonomski vidici. 16(3), (str. 572-588)

[11] Jokić D. (2010). Preduzetništvo. Užice: Naučno istraživački centar (NIC) Užice.

[12] Jokić, D. i Mikić, A. (2008). Marketing komunikacije. Užice: Naučno istraživački centar.

[13] Mašić B. (2010). Menadžment. Beograd: Univerzitet Singidunum.

[14] Milosavljević, M., (2006). Strategijski marketing. Beograd: Ekonomski fakultet.

[15] Milosavljević M., Veionović M. i Grubor G. (2013), Informatika. Beograd: Univerzitet Singidunum.

[16] Milošević, D. (2014). Strategija rasta i razvoja preduzeća. Beograd: Visoka škola za poslovnu ekonomiju i preduzetništvo.

[17] Njeguš A. (2009). Poslovni informacioni sistemi, Beograd: Univerzitet Singidunum.

[18] Njeguš A. (2010). Informacioni sistemi u turističkom poslovanju. Beograd: Fakultet za turistički i hotelijerski menadžment, Univerzitet Singidunum.

[19] Obradović, S., Jevtić, B., Grozdanić, R., Damnjanović, A., i Vulović, R. Uloga IKT u koordinaciji intermodalnog transporta. 14. Međunarodna konferencija Upravljanje kvalitetom i pouzdanošću ICDQM-2011, 29-30. jun 2011. (str. 737-744). Čačak: Istraživački centar za upravljanje kvalitetom i pouzdanošću - DQM.

[20] Ožegović L. i Sajfert Z. (2009). Preduzetništvo. Novi Sad: Fakultet za ekonomiju i inženjerski menadžment.

[21] Papić, Lj. (2011). Menadžment kvalitetom. Čačak: Istraživački centar za upravljanje kvalitetom i pouzdanošću.

[22] Ranđić, D. i Lekić, S. (2009). Menadžment. Beograd: Beogradska poslovna škola.

[23] Ratković, M., Grubić, G., Tasić, S., Damnjanović, A., i Matić, R., Dobri odnosi sa kupcima kao faktor konkurentske prednosti. 14. Međunarodna konferencija Upravljanje kvalitetom i pouzdanošću ICDQM-2011, 29-30. jun 2011. (str. 180-186). Čačak: Istraživački centar za upravljanje kvalitetom i pouzdanošću-DQM.

[24] Šarac M., Jevremović A. i Radovanović D. (2015). Internet marketing. Beograd: Fakultet za informatiku i računarstvo, Univerzitet Singidunum.

[25] Veljović, A., Vulović, R. i Damnjanović, A. (2009). Informaciono komunikacione tehnologije u menadžmentu. Čačak: Tehnički fakultet.

[26] Vemić, M., (2008). Nauka o privrednom sistemu i ekonomskoj politici u tranziciji. Novi Sad: Cekom books.

[27] Vukadinović P. i Jović Z. (2012). Investicije. Beograd: Univerzitet Singidunum.

[28] Živadinović, J., (2010). Poslovna informatika. Beograd: Visoka škola za poslovnu ekonomiju i preduzetništvo. 